\title{
The Doctrine of Double Effect: An Aid in Decision-Making
}

\author{
Doktryna podwójnego skutku: pomoc w podejmowaniu decyzji
}

\author{
Pavol Dancák \\ Department of Philosophy and Religion, University of Presov, Slovakia \\ ORCID: https://orcid.org/0000-0002-8067-5651•pavol.dancak@unipo.sk \\ Received: 09 Aug 2020; Revised: 18 Sep 2020; Accepted: 20 Sep 2020
}

\begin{abstract}
Human society of the modern world, which is greatly affected by technological and economic advancements, has to address moral problems with a new urgency. In many instances, the decision does not bring only positive effects. Such cases can be found in applied ethics: bio-medical ethics, business ethics, and legal ethics, but also in other areas of human activity, too, most recently, in debates, concerning the use of autonomous vehicles or autonomous machines in general. This paper aims to describe and explain the principle of 'double effect', when solving complicated and, from the perspective of morality, profoundly dilemmatic situations. The principle of double effect was gradually developed as a means of seeking the right moral decisions. It has a firm and respected position within Catholic medical ethics, but also in secular legislation. The paper presents current thought experiments, which clarify moral decision-making in dilemmatic situations. What seems to be a shortcoming here, is that ethical thought experiments are far too abstract. On the one hand, they refine our knowledge, but on the other hand, they are very partial. The evolution of medical imaging methods, has enabled us to take a closer look at the relationship between the deontological and utilitarian approaches to making moral judgments, but it does not relieve us of our responsibility for the decisions that we have made. The positive side of the principle of double effect, is that it protects us from the slippery slope of utilitarian consequentialism, where the admission of a lesser evil, is only a step away from committing evil in the name of the greater good.
\end{abstract}

Keywords: moral dilemmas, medical ethics, principle of double effect, utilitarian consequentialism

Streszczenie: Współczesne społeczeństwa, będące pod ogromnym wpływem postępu technologicznego i gospodarczego, muszą poważnie traktować różnego rodzaju problemy moralne. W wielu przypadkach podejmowane przez ludzi decyzje przynoszą efekty nie tylko pozytywne. Analizą takich sytuacji zajmuje się etyka stosowana: etyka biomedyczna, etyka biznesu, etyka prawna. Podobne przypadki można także spotkać w dyskusjach dotyczących m.in. wykorzystania pojazdów i maszyn autonomicznych. Celem niniejszego artykułu jest opisanie i wyjaśnienie zasady podwójnego skutku w kontekście rozwiązywania skomplikowanych sytuacji moralnych z etycznego punktu widzenia. Zasada podwójnego skutku była stopniowo rozwijana jako środek poszukiwania właściwych decyzji moralnych. Posiada ona mocną i uznaną pozycję w katolickiej etyce lekarskiej, ale także w świeckim ustawodawstwie. Artykuł przedstawia aktualne eksperymenty myślowe, które wyjaśniają podejmowanie decyzji moralnych w skomplikowanych sytuacjach. Wydaje się, że wspókczesne etyczne eksperymenty myślowe są zbyt abstrakcyjne. Z jednej strony, udoskonalają naszą wiedzę, z drugiej - są bardzo stronnicze. Ewolucja metod obrazowania medycznego umożliwiła nam bliższe przyjrzenie się związkom między deontologicznym i utylitarnym podejściem do wydawania sądów moralnych, ale nie zwalnia nas z odpowiedzialności za podjęte przez nas decyzje. Pozytywną stroną zasady podwójnego skutku jest to, że chroni nas ona przed śliskim zboczem konsekwencjalizmu utylitarnego, w którym przyznanie się do mniejszego zła jest tylko krokiem od popełnienia zła w imię większego dobra.

Słowa kluczowe: dylematy moralne, etyka medyczna, zasada podwójnego skutku, utylitarny konsekwencjalizm 


\section{Introduction}

In real life, people are constantly confronted with situations in which they have to make decisions that do not always have only good effects. Dilemma situations have always been a part of our lives and their solution requires proper ethical reflection. In Book I of Plato's Republic, Cephalus defines "justice" as speaking the truth and paying one's debts. Socrates quickly refutes this account by suggesting that it would be wrong to repay a weapon to someone who could harm others with it. What we see here is a conflict between two moral norms: paying off debts and protecting others from harm. Socrates maintains that protecting others from harm is the norm that takes priority over paying off a debt (Plato 2006, 331c).

The conflict between the two moral norms is also described by Sophocles, when Antigone, in Sophocles's play of the same name, ought to arrange for the burial of her brother, Polyneices, and ought to obey the pronouncements of the city's ruler, Creon; she can do each of these things, but not both. There is a myriad of such cases, where a moral subject can do each of these things, but not both at the same time, and not only in literature. These instances can be found in applied ethics, e.g. biomedical ethics, business ethics, legal ethics, etc., but most recently also in debates concerning the use of autonomous vehicles or autonomous machines in general.

The principle of double effect was created as a means of seeking the right moral decisions. It is regularly used in ethical discussions on palliative sedation, terminal extubation, and other clinical acts that can be considered as those that accelerate the process of dying in terminally ill patients. Unfortunately, there is a tendency to use this useful principle in a way that should justify any kind of action, while ignoring the need to reflect on other moral principles (Rembierz 2015, 501-516; Valčo 2015, 129-139).

The principle of double effect has a firm and respected position within the Catholic medical ethics. Neil M. Gorsuch, a judge on the U.S. Court of Appeals for the Tenth Circuit who believes that this doctrine is central to U.S. law, adds relevancy to the current discussion on the question raised in our paper (Allsopp 2011, 31-40). The paper aims to describe and explain the principle of double effect when solving complicated and, from the perspective of morality, profoundly dilemmatic situations. There are two antagonistic positions that are key elements of every moral dilemma:

- the moral subject is obliged to perform two or more acts,

- the moral subject is able to perform only one act.

It seems that no matter what the moral subject decides to do, he or she is doomed to moral failure. Regardless of what the moral subject does, he or she will either do something wrong or will not do what he or she is obliged to do.

\section{On the principle of double effect}

The basic variant of the principle of double effect claims that under certain circumstances it is morally permissible to perform an action that has both good and bad effects. According to a common belief of moral philosophers, an explicit formulation and application of the principle of double effect can be assigned to the greatest Dominican thinker of High Scholasticism, St. Thomas Aquinas. However, Joseph T. Mangan points out that this principle, in its implicit form, can be found in the sixth chapter of the First Book of Maccabees (Mangan 1949, 42). ${ }^{1}$ The Old Testament text speaks of Eleazar, who

1 "Eleazar, called Avaran, noticing that one of the elephants was royally caparisoned and was also taller than all the others, and supposing that the king was mounted on it, sacrificed himself to save his people and win an imperishable name. Boldly charging towards the creature through the thick of the phalanx, dealing death to right and left, so that the enemy scattered on either side at his onslaught, he darted in under the elephant, thrust at it from underneath, and killed it. The beast collapsed on top of him, and he died on the spot." (1Macc 6:4346) 
decided to sacrifice himself for the sake of his people by sliding under the elephant carrying the king of the enemy and stabbed it to death from beneath. Eleazar did not wish to die, he did not intend to commit suicide, but wanted to kill the enemy knowing that he would not be able to escape from the falling elephant and would perish as a result. His death was not intended; it was foreseen as a necessary part of a positive moral act - the salvation of his own people.

Before Thomas Aquinas, the issue of actions that have both good and bad effect was discussed by St. Augustine in De Libero Arbitrio. He analyzes the permissibility of killing a person in two situations:

a. in a case of defense against an assassin (insidiator sicarius),

b. in a case of the killing of an attacking enemy (hostis inruens) during the war.

Augustine thus faces the question of whether some form of intentional killing can be considered as an act that is not evil and sin, since intentional killing of another human being is a sin according to the God's Commandments. Augustine asserts that killing in self-defense is a sin and an evil act since it is motivated by a passion for earthly life. Therefore, defending one's own ephemeral life cannot justify killing of another person, because it is something that does not fully belong to a human. Earthly life is not the real possession of a person, since it can be taken away from him against his will. In the same vein, Augustine adds that self-defense can be considered a lesser evil, because it is a milder evil to kill a criminal than an innocent person (Augustinus 1955) ${ }^{2}$. Augus-

2 St. Aurelius Augustinus: De Libero Arbitrio. 1.5.12.33. "Legem quidem satis video esse munitam contra huiuscemodi accusationem, quae in eo populo quem regit minoribus malefactis, ne maiora committerentur, dedit licentiam. Multo est enim mitius eum, qui alienae vitae insidiatur quam eum, qui suam tuetur, occidi, et multo est immanius inuitum hominem stuprum perpeti quam eum, a quo illa vis infertur, ab eo cui inferre conatur, interimi. Iam vero miles in hoste interficiendo minister est legis; quare officium suum facile nulla libidine tine's position on the question of self-defense is based on his conception of human as a morally developing being in the process of a struggle between good and evil. This concept is pacifistic in nature, since a Christian cannot intentionally deprive another human being of his or her life, even if human law allows it. Christians are bound by the superior eternal law which determines the limits of their action and on the basis of which intentional killing in such circumstances is a sin (Koniar 2009, 15-36). Augustine's theory of righteous war, just as the principle of double effect, attempts to explain permissible violence and harm. These are theories specifying situations when it is morally permissible to harm or even kill another human being. The application of the principle of double effect in some specific instances, such as justification of civilian casualties in time of war, becomes questionable (Buzar 2020, 1299-1312).

St. Thomas Aquinas's treatise on the possibility of permitted self-defense is based on a scholastic tradition. He refers mainly to St. Alan of Lille ${ }^{3}$ and Alexander of Hales. ${ }^{4}$ In his De Fide Catholica, Alan of Lille states that a defender can fend off the aggressor by

implevit." 1.5.12.35 "Porro ipsa lex, quae tuendi populi causa lata est, nullius libidinis argui potest, siquidem ille qui tulit, si dei iussu tulit, id est quod praecipit aeterna iustitia, expers omnino libidinis id agere potuit. Si autem ille cum aliqua libidine hoc statuit, non ex eo fit, ut legi cum libidine obtemperare necesse sit, quia bona lex et a non bono ferri potest." 1.5.12.36 "Non enim si quis verbi causa tyrannicam potestatem nanctus ab aliquo, cui hoc conducit, pretium accipiat, ut statuat nulli licere vel ad coniugium feminam rapere, propterea mala lex erit, quia ille iniustus atque corruptus hanc tulit. Potest ergo illi legi, quae tuendorum civium causa vim hostilem eadem vi repelli iubet, sine libidine ob, temperari; et de omnibus ministris, qui iure atque ordine potestatibus quibusque subiecti sunt, id dici potest."

3 St. Alan from Lille, (Latin: Alanus ab Insulis, 1128-1202/3), French Cistercian monk, philosopher, theologian, representative of early scholasticism.

4 Alexander from Hales (Alexander Halensis, 1185-1245) philosopher, theologian, and representative of Franciscan school. 
force even if he dies as result, if his death is not intended (non intendendo eum occidere). In his Summa Theologica, Alexander of Hales focuses primarily on the intention to preserve one's own life (intentio conservationis propriae salutis). In the respondeo, Thomas Aquinas first argues on the general level of the theory of human action. He states that a certain act can have two effects (unius actus esse duos effectus), one of which is intended (in intention), while the other is not (praeter intentionem). Thomas endorsed a doctrine according to which the moral character of human action is specified by its object, which determines the type of the act itself (morales autem actus recipiunt speciem secundum quod intenditur) (McInerny 1992, 80-81; McInerny 1997, 159-182).

The principle of double effect is found in the Summa Theologiae IIaIIae, q. 64 a. $7 .{ }^{5}$ where the Angelic Doctor discusses

5 Thomas Aquinas: Summa Theologiae. IIaIIae, q. 64, a. 7. "Respondeo dicendum quod nihil prohibet unius actus esse duos effectus, quorum alter solum sit in intentione, alius vero sit praeter intentionem. Morales autem actus recipiunt speciem secundum quod intenditur, non autem ab eo quod est praeter intentionem, cum sit per accidens, ut ex supradictis patet. Ex actu igitur alicuius seipsum defendentis duplex effectus sequi potest: unus quidem conservatio propriae vitae; alius autem occisio invadentis. Actus igitur huiusmodi ex hoc quod intenditur conservatio propriae vitae, non habet rationem illiciti: cum hoc sit cuilibet naturale quod se conservet in esse quantum potest. Potest tamen aliquis actus ex bona intentione proveniens illicitus reddi si non sit proportionatus fini. Et ideo si aliquis ad defendendum propriam vitam utatur maiori violentia quam oporteat, erit illicitum. Si vero moderate violentiam repellat, erit licita defensio: nam secundum iura, vim vi repellere licet cum moderamine inculpatae tutelae. Nec est necessarium ad salutem ut homo actum moderatae tutelae praetermittat ad evitandum occisionem alterius: quia plus tenetur homo vitae suae providere quam vitae alienae. Sed quia occidere hominem non licet nisi publica auctoritatae propter bonum commune, ut ex supradictis patet; illicitum est quod homo intendat occidere hominem ut seipsum defendat, nisi ei qui habet publicam auctoritatem, qui, intendens hominem occidere ad sui defensionem, refert hoc ad publicum bonum: ut patet in milite pugnante offenses against commutative justice and asks whether it is viable to kill an attacker in self-defense (utrum alicui liceat occidere aliquem se defendendo). He answers that nothing hinders one act from having two effects, only one of which is intended, while the other is beside the intention (Chyrowicz 1997, 48).

"Now moral acts take their species according to what is intended, and not according to what is beside the intention, since this is accidental as explained above. Accordingly, the act of self-defense may have two effects, one is the saving of one's life, the other is the slaying of the aggressor. Therefore, this act, since one's intention is to save one's own life, is not unlawful, seeing that it is natural to everything to keep itself in "being," as far as possible. And yet, though proceeding from a good intention, an act may be rendered unlawful, if it be out of proportion to the end. Wherefore if a man, in self-defense, uses more than necessary violence, it will be unlawful: whereas if he repel force with moderation his defense will be lawful, because according to the jurists, "it is lawful to repel force by force, provided one does not exceed the limits of a blameless defense." Nor is it necessary for salvation that a man omit the act of moderate selfdefense in order to avoid killing the other man, since one is bound to take more care of one's own life than of another's. But as it is unlawful to take a man's life, except for the public authority acting for the common good, as stated above, it is not lawful for a man to intend killing a man in self-defense, except for such as have public authority, who while intending to kill a man in self-defense, refer this to the public good, as in the case of a soldier fighting against the foe, and in the minister of the judge struggling with robbers, although even these sin if they be moved by private animosity" (Aquinas 2006, IIaIIae, q. 64, a. 7).

contra hostes, et in ministro iudicis pugnante contra latrones. Quavis et isti etiam peccent si privata libidine moveantur." 
This Aquinas' text is considered to be historically first application of ethical thinking based on the principle of double effect. It is set within the context of his perfectionist conception of morality (Timmons 2013, 75), where human life is one of perfection, which is a condition for realization of all other goods and as such, it is the subject of natural inclinations (Finnis 2011). Human action that aims to preserve the good of life is not ethically unacceptable because it is natural for man to want to continue his own existence for as long as possible. Although the inclination to life as good is natural, it does not follow that every way of preserving one's own life is morally justified (Černý 2015, 23).

Aquinas's contribution to decision-making of a moral subject in the moral dilemmatic situation of killing the aggressor in selfdefense can also be seen in the context of his treatise De bonitate et malitia humanorum actum in generali on moral character of human action in Prima secundae, q. $18 .^{6}$

6 Cf. Thomas Aquinas: Summa Theologiae. IaIIae, q. 18. "Respondeo dicendum quod ex his quae manifeste vivunt, accipere possumus quorum sit vivere, et quorum non sit vivere. Vivere autem manifeste animalibus convenit, dicitur enim in libro de vegetabilibus, quod vita in animalibus manifesta est. Unde secundum illud oportet distinguere viventia a non viventibus secundum quod animalia dicuntur vivere. Hoc autem est in quo primo manifestatur vita, et in quo ultimo remanet. Primo autem dicimus animal vivere, quando incipit ex se motum habere; et tandiu iudicatur animal vivere, quandiu talis motus in eo apparet; quando vero iam ex se non habet aliquem motum, sed movetur tantum ab alio tunc dicitur animal mortuum, per defectum vitae. Ex quo patet quod illa proprie sunt viventia, quae seipsa secundum aliquam speciem motus movent; sive accipiatur motus proprie, sicut motus dicitur actus imperfecti, idest existentis in potentia; sive motus accipiatur communiter, prout motus dicitur actus perfecti, prout intelligere et sentire dicitur moveri, ut dicitur in III de anima. Ut sic viventia dicantur quaecumque se agunt ad motum vel operationem aliquam, ea vero in quorum natura non est ut se agant ad aliquem motum vel operationem, viventia dici non possunt, nisi per aliquam similitudinem.“
Here Thomas speaks about the conditions determining moral evaluation (fontes moralitatis) (Osborne 2014, 149-152) of human deeds against the backdrop of the general metaphysical assumption that every thing, including human action, has as much good as it has being, which pertains to it from its essence (Wippel 2020, 44). The only absolute being, the fullness of being (plenitudo essendi) is God who is as esse ipsum subsistens the absolute good, the complete subsisting perfection. Human action cannot, by its nature, be the absolute good, but it can attain such fullness of being which belongs to it as human action. And it is good to the extent to which this relative fullness of being belongs to it. On the opposite note, it is bad to the extent to which human action does not attain the fullness of being that belongs to it (Aquinas 2006, IaIIae, q. 18, a. 1,4).

According to Thomas Aquinas, the goal (finis) is the last source of the morality of human action, because action is determined not only by its object (finis operis), but also the goal of the actor (finis operantis), since the action of rational actors is always focused on some goal (Aquinas 2006, IaIlae, q. 18, a. 4). Acquinas deems the relationship between finis operis and finis operantis complicated. According to the Angelic Doctor, finis operantis can give a new character to an already formally determined act by its object (Aquinas 2006, IaIIae, q. 7, a. 4, ad 2). Thomas gives a simple example: Let us imagine that someone steals money in order to seduce a woman and commit an act of adultery. From the point of view of the specification by the act's object, it is a theft, but with regard to the aim of the agent (finis operantis) it is adultery. So that someone who committed theft is in fact an adulterer since he stole the money so that he could commit adultery (Smith 1991, 217; Černý 2015, 211).

\section{Circumstances of actions}

Human being is a substantial unity that does not immediately and completely determines 
the perfection that a human being can attain Human being is also a bearer of accidents that contribute to the full determination of his being as a human. It is similar when human action is concerned. Its moral perfection is also determined by external accidental factors - circumstances of the action (circumstantiae). For example, an action that, from an impartial point of view, can be described as transferring a certain amount of money into one's own pocket.

If it is someone else's money and the money is being transferred to one's own pocket illegally, it is a theft from a moral point of view. We judge this act differently knowing whether the thief is a stranger or a custodian of the property that belongs to the person being robbed. The fact that a thief is a stranger in one instance and a person entrusted with the financial custody of stolen property in another does not enter into essential determination of the act or into its moral specification. Theft is always a theft. There is, however, another circumstance making the theft on the part of the custodian a morally graver offence (Oderberg 2000, 67). In the Nicomachean Ethics, Aristotle mentions six such circumstances affecting freedom, but also the moral value of an action (Volek 2011, 1123). He summarizes them into questions: Who is the actor?; What is the actor doing?; What or who affects his action? Why and how does he act? In different section of the text Aristotle mentions three circumstances: object, instrument, and purpose, and four or three, depending on how one categorise them, others elsewhere in the text (Aristotle 2009).

An important part of Thomas Aquinas's doctrine of fontes moralitatis is the conviction that human action is morally determined by all three factors: object, goal, and circumstance. There are usually seven circumstances: quis, quid, ubi, quibus auxiliis, cur, quomodo, quando. Sometimes circumstances become part of the object of the action and modify the type of action (Mangan 1949, 47). Morally proper action is one that is proper from the point of view of object, circumstances and goal (bonum ex integra causa). A defect in one of these sources of morality is sufficient for the action to be wrong (malum ex quocumque defectu) (Finnis 1991, 16-17). Let us explain this with an example: a good surgeon is characterized by three abilities: a) excellent theoretical knowledge and practical skills, b) coolheadedness, c) sobriety. A good surgeon is one who uses his theoretical knowledge during surgery and has excellent surgical technique. He reacts calmly, level-headedly in difficult situations and is, of course, sober. If one of these components is defective, then the surgeon cannot be considered a good surgeon in a given situation. Human action is in its moral dimension as a work of art: one defect reduces its value (Černý 2015, 20).

In the incident of killing the aggressor during the defense of one's own life, the object of the action is good (resistance by power) and also the goal of the actor is good (the actor wants to save his own life). Thomas Aquinas defines circumstances as using the means appropriate to the goal and in accordance with the doctrine that is generally outlined in Prima Secundam, q. 18 as follows: if the means is adequate to the purpose, it is a morally permissible conduct, but if it is not adequate, the conduct is not morally permissible. Based on the historical-moral debate on the principle of double effect, which in fact is an ongoing process in various theoretical contexts, it was established in the formulation from J.P. Gury (1801-1886) that one act, which has both good and bad effects, can be performed unless following four conditions are observed:

1. An act is in itself good or indifferent.

2. The intention of the actor is directed only to the good effect, while the bad effect is only tolerated or admitted.

3. A bad effect is not a means to achieve a good effect.

4. There is an adequate proportion between the good and bad effect (Faggioni 2007, 74). 


\section{Trolley problem}

In 1967, the British philosopher Philippa Foot (1920-2010) published an article entitled "The Problem of Abortion and the Doctrine of the Double Effect," in which she introduced a thought experiment involving a trolley heading unstoppably towards a switch (Foot 1981). ${ }^{7}$ There are five people lying tied up on one track and only one on the other one. The trolley driver cannot apply the brakes. If he does nothing, the trolley will continue on the track and kill five people. However, if the driver diverts the trolley, he will kill only one. What should he do?

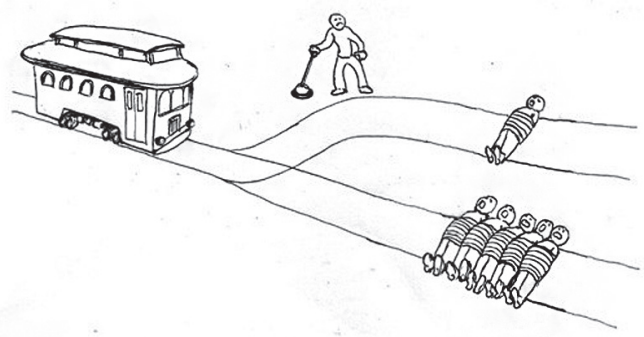

Illustration 1: Source: https://medium.com/ jigarjain/moral-reasoning-the-trolley-problem1 bfa17e83ofa

Is it right for the driver to divert the trolley onto the tracks where only one person is lying? Is it right to kill one instead of five workers? Applying the logic of the principle of double effect killing one person is an indirect intention resulting from the driver's efforts to save five people and therefore he should divert the trolley (Foot 1981, 23). Foot comes up with another similar example: a

7 Foot had no idea that her thought experiment would become the subject of an ongoing discussion called trolleyology. A number of prominent philosophers have focused their attention on examining a situation in which a tram, a trolley, or a train is out of control and approaches a switch, a bridge, a loop, a turntable, and killing five unfortunates if no one intervenes. The driver can change the direction of the vehicle, a random passer-by can flip a switch, another random passer-by can throw a very obese man off a bridge as a weight to stop the trolley. There is a decision-making between saving one or five lives. seriously ill patient is in hospital and needs the full dose of medicine to recover. The only dose that is available. After that, another five patients come to the hospital (Foot $1981,24)$. Only one-fifth of this dose would be enough for each of them to recover. Is it right to sacrifice one patient for five? The same question arises for another version of the example, in which we have one person and five patients who need a transplant of different organs. To obtain them, it would suffice to sacrifice just one person. From the point of view of utilitarianism, both cases are equal. From the point of view of the principle of double effect, there is a difference that prevents us from deciding the same "in favour" of one person dying in both situations. The difference is that in the first case scenario we do not wish for the person to die, but in the second one we do (Chyrowicz 2003, 256-273).

Foot proposes a solution that is not apllicable universally but is still better than the principle of double effect. She proposes to distinguish between positive and negative obligations (Foot 1981, 27). She was inspired by J. Bentham and his division of actions into positive and negative. Positive obligations are those we should strive for, and negative obligations are those we should avoid (Bentham 1823). The examples given by Foot involve providing help and avoiding harm to the people. Regarding the trolley problem, the solution is simple, since the driver decides between negative obligations in both situations. Therefore, he should act in a way that brings as little harm as possible. The driver has to change direction and kill one person instead of five (Foot 1981, 19).

The scenarios involving patients are more complicated. In a situation when we decide about distribution of the dose among the patients, we consider two positive obligations. In the case scenario involving organ donation, there are positive and negative obligations that are in opposition. We could even say that we would not kill that one person; we will "only" let him die. For example, we could not give food to 
the patient. According to Foot, most of us tend to prefer negative obligations over the positive ones. Here, the doctor should not sacrifice one person for the benefit of five other patients (Foot 1981, 28).

The English philosopher acknowledged that there are numerous factors we must take into account when considering individual situations (Foot 1981, 29). Her aim was not to offer one final solution. She performed all thought experiments to show that when abortions are concerned it is not always appropriate to apply the principle of double effect. She concluded that it was much more important to distinguish between positive and negative obligations.

\section{Dual-process theory of moral judgment}

The "Trolley Problem" inspired by the thinking of Thomas Aquinas and elaborated further by the American philosopher Judith Jarvis Thomson (Thomson 1985, 1396-1397; Thomson 1976, 206), sparks interest of contemporary thinkers, too. Using the latest imaging techniques (functional magnetic resonance imaging), Joshua Greene ${ }^{8}$ examined the reactions of people in an experiment where there is no switch on the track, but there is a bridge over the track on which there is a tourist and an obese man leaning over the railings of the bridge. The tourist sees a trolley approaching very fast assuming that the brakes are probably not working. There are five people lying tied up to the tracks. If the trolley does not stop it will kill all five people on that track. The tourist realizes that if he pushes the obese man off the bridge and he falls in front of the trolley, then the trolley would stop and would not run into these five persons (Greene 2016, 173-189).

8 Joshua D. Greene is an American experimental psychologist, neuroscientist, and philosopher. He is a Professor of Psychology at Harvard University. Most of his research and writing has been concerned with moral judgment and decision-making. His recent research focuses on fundamental issues in cognitive science.

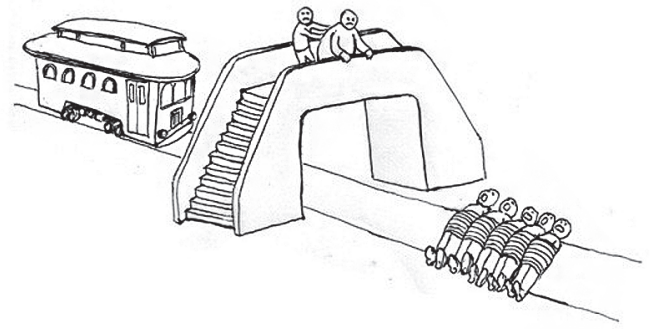

Illustration 2. Source: https://www.engineering. com/resourcemain.aspx? resid $=816$

Based on his research, Joshua Greene is convinced that our moral judgments are based on emotions and reasoning. Thus, no specific brain area is responsible for our moral decisions (Haidt 2002, 522). Our actions are associated with two processes: emotions and the ability to think about these actions. That is where the name "The Dual-Process Theory of Moral Judgement" is derived from. The interplay of both processes creates human moral reasoning (Evans 2008, 255-278; Kahneman 2011, 77). Based on this reasoning, Joshua Greene divided moral actions into personal and impersonal. Disruption of moral actions is classified "personal" if it causes:

- serious bodily harm,

- to a particular person or group, where

- the harm does not result from deflecting an existing threat.

The rest were classified as "impersonal" (Greene 2009, 581-584). Joshua Greene found that thinking about personal moral dilemmas, including thinking about a bridge dilemma, involves those areas of the brain that are associated with emotions. ${ }^{9}$ In impersonal moral dilemmas, such as the first version of the trolley, the parts of the brain that are related to cognitive control, reasoning, and working memory are activated. ${ }^{10}$ The decision-making process is more under control and tends not to provoke large emotional reactions (Greene 2001, 2105-2108). Decision-making is driven

9 It is associated with activity in the amygdala and in the ventromedial prefrontal cortex.

10 It is related to activity in the dorsolateral prefrontal cortex. 
by the desire to save as many lives as possible and has a utilitarian and consequentialist character.

The theory of dual processes, developed by research using fMRI, confirms that our moral judgments are subject to the influence of emotions and rational reasoning (Hare 1997, 132). It deepens our knowledge of the way of decision-making, but nevertheless the whole weight of decision-making in a dilemmatic situation remains on the shoulders of the individual.

\section{Conclusion}

With increasing urgency, technological and economic development of human community places before us a new set of ethical problems that require solutions. What seems to be a shortcoming here is that ethical thought experiments are far too abstract. On the one hand, they refine our knowledge, but on the other hand, they are rather partial.

In the trolley experiment, we do not even know who these people on the tracks are. The general term "workers" is very misleading. After all, we need to know whether the person standing next to us is a relative, a friend or a genius and whether there are no murderers down on the track. Truly, we will decide differently knowing that there is a saint and a philanthropist standing next to us, while Hitler, Stalin, Mengele, Pol Pot and Beria are those five people on the track. The research in which we have to make decisions without context is rather problematic. Moreover, in fact the principle of double effect cannot be adequately applied without referring to moral theories that are not explicitly stated in the principle itself (Billings 2011, 437-440).

Nevertheless, the above mentioned principles and thought experiments help us with moral decision-making that is not straightforward and simple, but, at the same time, they do not and should not be used as an anesthetic for our conscience. On the positive side, the principle of double effect protects us from the slippery slope of utilitarian consequentialism, where the admission of lesser evil is just a step away from committing evil in the name of greater good. It also helps us to find out what is the best and what we can really do, without having to defend the actions of lesser evil.

\section{Bibliography}

Aristotle. 2009. The Nicomachean Ethics. New York: Oxford University Press.

Aquinas, Thomas. 2006. Summa theologiae. Cambridge, UK: Cambridge University Press.

Allsopp, Michael E. 2011. "The Doctrine of Double Effect in U.S. Law. Exploring Neil Gorsuch's Analyses." National Catholic Bioethics Quarterly 11: $31-40$

Augustinus, Aurelius. 1955. De Libero Arbitrio. London: Newman Press.

Bentham, Jeremy. 1823. Introduction to Principles of Morals and Legislation. http://www.econlib.org/ library/Bentham/bnthPMLCover.html.

Billings, Andrew J. 2011. "Double Effect: A Useful Rule that Alone Cannot Justify Hastening Death." Journal of Medical Ethics 37: 437-440.

Buzar, Stipe. 2020. "The Principle of Double Effect and Just War Theory." Philosophia 48: 1299-1312. https://doi.org/10.1007/s11406-020-00209-2.

Chyrowicz, Barbara. 1997. Zamiar i skutki. Filozoficzna analiza zasady podwójnego skutku. Lublin: Towarzystwo Naukowe Katolickiego Uniwersytetu Lubelskiego.

Chyrowicz, Barbara. 2003. "Tramwaj i ustawa. O sytuacjach «bez wyjścia» w etyce." Ethos 1-2: 256-273.

Černý, David. 2015. Princip dvojího účinku. Praha: Univerzita Karlova v Praze.

Evans, Jonathan. 2008. „Dual-Processing Accounts of Reasoning, Judgment, and Social Cognition." Annual Review of Psychology 59(1): 255-278.

Faggoni, Maurizio. 2007. Život v našich rukách. Spišská Kapitula: Nadácia Kňazského seminára biskupa Jána Vojtaššáka.

Finnis, John. 1991. Moral Absolutes. Tradition, Revision, and Truth. Washington, D. C.: The Catholic University of America Press.

Finnis, John. 2011. Natural Law and Natural Rights. Oxford: Clarendon.

Foot, Philipa. 2002: "The Problem of Abortion and the Doctrine of the Double Effect." In Virtues 
and Vices and Other Essays in Moral Philosophy, edited by Philippa Foot, 19-32. Oxford: Clarendon.

Greene, Joshua, R. Brian Sommerville, Leigh E. Nystrom, John M. Darley, Jonathan D. Cohen. 2001. "An fMRI Investigation of Emotional Engagement in Moral Judgment." Science 293: 2105-2108. https://doi.org/10.1126/science.1062872.

Greene, Joshua. 2009. "Dual-process Morality and the Personal/Impersonal Distinction: A Reply to McGuire, Langdon, Coltheart, and Mackenzie." Journal of Experimental Social Psychology 45(3): 581-584.

Greene, Joshua, and Jonathan D. Haidt. 2002. "How (and Where) Does Moral Judgment Work?” Trends in Cognitive Science 6(12): 517-523.

Greene, Joshua. 2016. "Solving the Trolley Problem." In A Companion to Experimental Philosophy, edited by Justin Sytsma and Wesley Buckwalter, 173-189. Chichester: John Wiley \& Sons.

Hare, Richard. 1997. “Utilitarizmus.” In Súčasná politická filosofie, edited by János Kis, 123-142. Praha: Oikoymenh.

Kahneman, Daniel. 2011. Thinking, Fast and Slow. New York: Farrar, Straus and Giroux.

Koniar, Ivan. 2009. "Zdôvodnenie vojny v prácach sv. Augustína." Studia theologica 11, no. 4(38): 15-36.

Mangan, Joseph. 1949. "An Historical Analysis of the Principle of Double Effect.” Theological Studies 10: 41-61.

McInerny, Ralph. 1992. Aquinas on Human Action. A Theory of Practice. Washington, D.C.: The Catholic University of America Press.

McInerny, Ralph. 1997. Ethica Thomistica: The Moral Philosophy of Thomas Aquinas. Washington, D.C.: The Catholic University of America Press.
Timmos, Mark. 2013. Moral Theory. An Introduction. Lanham: Rowman \& Littlefield Publishers.

Osborne, Thomas M. Jr. 2014. Human Action in Thomas Aquinas, John Duns Scotus \& William of Ockham. Washington, D.C.: The Catholic University of America Press.

Oderberg, David. 2000. Moral Theory: A NonConsequentialist Approach. Oxford, UK: Blackwell Publishers.

Plato. 2006. Štát. Bratislava: Kalligram.

Rembierz, Marek. 2015. "Refleksja moralna nad odpowiedzialnością filozofa w XX wieku.” In Filozofia - Etyka - Ekologia, edited by Piotr Domeracki, Adam Grzeliński, and Ryszard Wiśniewski, 501-516. Toruń: Wydawnictwo Naukowe Uniwersytetu Mikołaja Kopernika.

Smith, Janet E. 1991. Humanae Vitae: A Generation Later. Washington D. C.: The Catholic University of America Press.

Thomson, Judith J. 1985. “The Trolley Problem.” The Yale Law Journal 94: 1396-1397.

Thomson, Judith J. 1976. "Killing, Letting Die, and the Trolley Problem." The Monist 59: 204-217.

Valčo, Michal. 2015. "Rethinking the Role of Kierkegaard's 'authentic Individual' in liberal capitalist Democracies Today." European Journal of Science and Theology 11(5): 129-139.

Volek, Peter. 2011. "Vplyv aristotelizmu pri vysvetlovaní konania u Tomáša Akvinského a Rajmunda Lulla." Filozofia 1: 11-23.

Wippel, John. 2000. The Metaphysical Thought of Thomas Aquinas. From Finite Being to Uncreated Being. Washington, D. C.: The Catholic University of America Press. 